\title{
加圧カを制御したパルス通電焼結による機能性材料の作製
}

\author{
小林 慶三 \\ 独) 産業技術総合研究所サステナブルマテリアル研究部門, ７ 463-8560 名古屋市守山区下志段味穴が洞 2266-98.
}

\section{Functional Materials Prepared by Pulsed Current Sintering Control the Use of Pressure}

\begin{abstract}
Keizo Kobayashi
National Institute of Advanced Industrial Science and Technology, Material Research Institute for Sustainable Development, 2266-98 Anagahora, Shimoshidami, Moriyama-ku, Nagoya 463-8560, Japan.
\end{abstract}

Received April 13, 2007

\section{SYNOPSIS}

A pulsed current sintering is a new sintering process that powder in the conductive mold is heated by applying current under a pressure. This new sintering process is able to apply high-speed heating and densification at lower sintering temperature. Therefore, this process is effective for consolidation of nanocrystalline materials.

In this study, we focus attention on the pressure during the pulsed current sintering of varied functional materials. In the ordinary pulsed current sintering process, the powder in the graphite die was consolidated under a pressure of about $30 \mathrm{MPa}$. The mechanically alloyed $\mathrm{Fe}-48$ at $\% \mathrm{Cr}$ powder was consolidated in this process without brittle phase. In addition, the $\mathrm{Fe}-48$ at\% $\mathrm{Cr}$ compact with a complex shape was able to be formed.

The pulsed current sintering under a pressure of less than $10 \mathrm{MPa}$ was effective to prepare the homogeneous porous materials. The porous material prepared by this process from copper fiber can be applied to heat sink for cooling CPU. The pulsed current sintering with a pressure of more than $500 \mathrm{MPa}$ was effective to consolidate amorphous powder and to obtain a bulk nanocrystalline compact at s sintering temperature more than crystallized temperature of the amorphous powder. The nanocrystalline $\mathrm{Ti}-2$ at $\% \mathrm{Fe}-10$ at $\% \mathrm{Si}$ compact had high strength and was applied to the mold for consolidation of $\mathrm{NaCl}$ powder.

\section{KEY WORDS}

pulsed current sintering, pressure, porous material, $\mathrm{Fe}-48$ at $\% \mathrm{Cr}$, nanocrystalline compact, $\mathrm{Ti}-2 \mathrm{at} \% \mathrm{Fe}-10$ at\% $\mathrm{Si}$

\section{1 緒言}

パルス通電焼結 (以下, PCS と記す) は，導電性の型に粉末

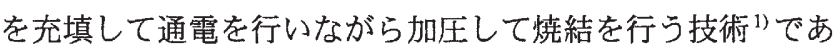
る. 原理的には，ホットプレス焼結に近い焼結技術と考えら れる.ただ，焼結する粉末が金属のように導電性がある場合 には, PCSでは粉末にも電流が流れるため少し焼結メカニズ $ム^{2.3)}$ が異なってくる. 金属粉末の表面には薄い酸化皮膜が形 成している場合が多いが, 型内に充填して加压した際に粉末 表面が擦れ，新しい面があらわれる．この状態で電気を流す と粉末の接触部分に電気が集中して流れるため, 粉末の接触 部分が高温となりネックが形成される.ネックが形成される 際に周辺の酸化膜を破壊し, ネックの成長が生じる. その後, 焼結理論にしたがって，ネックが成長して低温での焼結を実 現できるものと考えることができる.これまでは, プラズマ
が発生して焼結性を改善するという考えもあったが, 導電性 粉末の焼結においては未だ我々はプラズマの発生を確認でき ていない. また, セラミックス粉末のように非導電性粉末の 場合には型の通電加熱による加熱のみで焼結が進行するため, 基本的にホットプレスと同じ焼結機構と考えられる.ただ, ヒーターを用いたホットプレスに比べると，ヒーターで空間 を輻射加熱するのではなく成形型を直接加熱するため, エネ ルギー効率のよい高速の加熱を行うことができる.そのため, 同じ材料の焼結に要する時間が短くなり, 微細な組織を有す る焼結体を作製することができる.

本報告では, パルス通電焼結における焼結時の加圧力に着 目し,パルス通電焼結を用いた様々な機能性材料の作製技術 について解説を行う. 特に産業技術総合研究所サステナブル マテリアル研究部門相制御材料研究グループで取り組んでき 
た事例を基に報告する.

\section{2 パルス通電焼結と加圧力制御}

パルス通電焼結装置には, サイリス夕方式の電源を有する SPS シンテックス社製のSPS シリーズ，インバータ方式の電 源を有するエス・エス・アロイ社製の PLASMAN シリーズ, 焼結初期にパルス電流を付与しその後直流を付与するPASシ リーズなどが市販装置として存在する. 現在の普及率を見ると, ほとんどはSPS シリーズであろうと考えられる. 装置による 大きな差異はこれまでの研究で認めら狄ていないが, 黒鈶型を 用いた焼結においてはSPSシリーズが最も温度の制御性が良 いように感じる.ただ, インバータ方式の電源は小型化ができ る上, 直流加熱もできることから実験室レベルでは様々な研 究に応用することができる.電流は試料の加熱温度に反映され, 大きな電源を利用することで大型焼結体への利用が行われて いる.なお，パルス通電焼結では型材料として黒鉛が一般的 であり，焼結温度は黒鉛の抵抗加熱に依存する，型として黒 鈶は比較的安価であり,通電による抵抗発熱も良好であるが, 金属との反応がある上，金型に比べて低温での強度が低い．

パルス通電焼結において粉末を低温で緻密化するためには, 加圧力の影響も大きい. 代表的なパルス通電焼結装置の概略 を Fig.1に示す. パルス通電焼結の加圧機構としては, 油圧プ レスが一般的である.そのため, 最小加圧力として $300 〜 400$ $\mathrm{kg}$ 程度の荷重が粉末に付与される. また, 最大の加圧力は黒 鈶型の引張強度を基に $30 \sim 50 \mathrm{MPa}$ 程度に設定される. その ため, 油圧による加圧機構で黒鉛型を用いた標準的なパルス 通電焼結では加圧力の制御幅が小さくなってしまう. 低圧力 の成形を行うためには, 油圧以外の加圧機構が必要であり, サーボモーターを用いた加圧機構が採用されている装置もあ る. サーボモーターを用いた加圧機構では, ラムの位置制御 も可能となるが, 反面大きな圧力を発生させることは難しい， 大きな圧力を粉末に付与するためには, 油圧による加圧機構

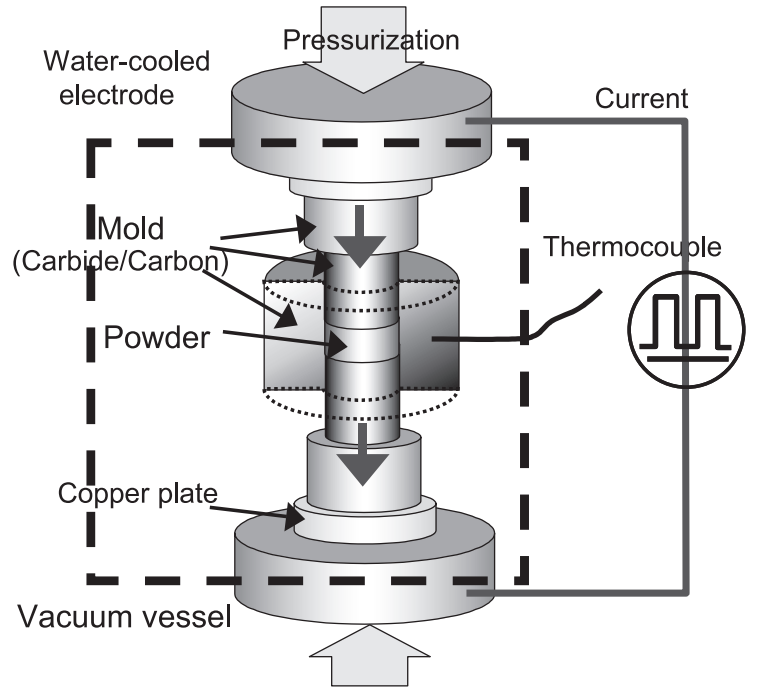

Fig.1 Schematic drawing of the apparatus for pulsed current sintering.
が有効であり, 型には引張強度の強い材料を用いる必要があ る.ただ，通電による抵抗発熱を利用するため，金属に比べ 電気抵抗の高い超硬合金などの複合材料が好ましい，超硬合 金は $800 \mathrm{~K}$ 程度までは高い引張強度を示すが，それ以上高温 になると軟化することが懸念される，そのため，超硬合金を 型として利用するためには, 軟化温度以下での使用に限られ る.これらのことから, 低圧でパルス通電焼結するためには, サーボモーターを利用した装置を用い, 高圧でパルス通電焼 結するためには油圧を利用した装置を利用することが適して いる. 低圧のパルス通電焼結では安定して通電を行うために 成形する粉末の形状や成形パンチの固定方法を検討する必要 がある. 電極にパンチを固定することで, 安定した通電を行 うことができた．また，超硬合金の型を用いて高圧でパルス 通電焼結する場合にも, パンチと電極の間にすきまが生じる と通電時に放電が生じる場合がある，それを防止するために は, 電極とパンチの間に電気抵抗が低く, 軟らかい金属ブ ロックを挿入することが勃果的であった，また，超硬合金製 型は黒鉛に比べ電気抵抗が低いため, 発熱効率が悪い。 その ため, 粉末を高速に加熱することが難しくなるため, 型の表 面からの熱輻射によるエネルギーのロスなどを抑制する必要 がある. 超硬合金製型(ダイス)の表面に黒鉛フェルトなどの 多孔質材料を巻くことが有効であった.

\section{3 加圧力を制御したパルス通電焼結による 機能性材料の作製}

3.1 低圧パルス通電焼結による多孔質材料の作製

銅繊維を用いて, パルス通電焼結による多孔質成形体の作 製を行った、銅䋐維は加熱することにより容易に軟化するた め, 加圧力をかなり小さくして焼結を行う必要がある. また, 纎維の接触部分のみを溶着させることが理想的な成形体の作 製方法であり，任意の気孔率を実現することができる，接触 部分での接合を強固にするために, 型には非導電性のガラス を用い, パンチには黒鉛を用いて焼結を行った. ダイセット の模式図をFig.2に示す. Fig.1のパルス通電焼結とは違い, 黒 鈶パンチは稼動する上ラムに固定されている. パンチの位置

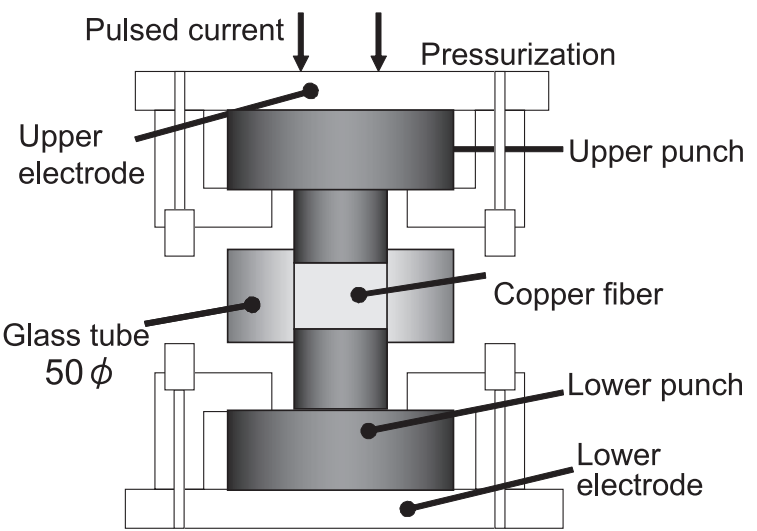

Fig.2 Schematic drawing of the apparatus for pulsed current sintering under a low pressure. 
を固定することで型内に押し込んだ銅繊維が復元する微小な 力で通電焼結することができる. 実際に内径 $50 \mathrm{~mm}$ のガラス 型の中に銅繊維を押し込み，通電する前の様子を Fig. 3 に示 す. 型であるガラス管とのクリアランスをできるだけ小さく した黒鈶パンチを用いることで均等に銅繊維を微小な力で押 すことができる.

PLASMANを用いて, $100 \mathrm{~Hz}$ のパルス電流を付与して焼結 を行った. 通電によって加熱された銅繊維は軟化するため加 圧力 (この場合は銅䋐維の復元力)は小さくなるが, 成形時の 圧力が $10 \mathrm{MPa}$ 以下で0にはならないように銅繊維の量を調整 した.パルス電流の大きさは成形体の空隙率に依存しており, 空隙率の小さな緻密体になるほど大きな電流が必要であった. 得られた成形体の外観を Fig.4に示す. 円柱の成形体を切断し て，それぞれの密度を測定したところ，中心部分がやや密度 が低いもののほぼ均質な成形体となっていることがわかった。 切断してもそれぞれの成形体は形状が変化することなく, 繊 維の接触部分が接合しているものと考えられる.

この銅の多孔質成形体をヒートシンクとして実際の CPU (Athron1800+)の上にセットしてみると,CPUからの熱伝達が 悪くヒートシンクとしての効率が悪いことがわかった. しか し, 一度伝達された熱はファン冷却を行うと急速に放散され ることも確認された。熱源であるヒートシンクから効率的に 熱伝達が行えれば, 多孔質銅はヒートシンクとして有望であ ると考えられる. そこで, 熱源と接触する部分にはバルク上 の銅を, 放熱部分には多孔質銅とコイル状の銅を組み合わせ たヒートシンク(Fig.5)を試作した. その結果，ほぼ同じ大き さのアルミニウム製ヒートシンクに比ベ，重量は 4 ～倍に なるが，ヒートシンクとしての性能は飛躍的に向上すること がわかった. ちなみに，アルミニウム製のヒートシンクでは パソコンのOSがスタートして 53秒で停止したが, Fig.5の多 孔質銅を利用した試作ヒートシンクでは 360 秒たっても停止 することはなかった. 360 秒後のヒートシンク温度は 310 〜 $320 \mathrm{~K}$ 程度で一定となっていた．銅製ヒートシンクを多孔質

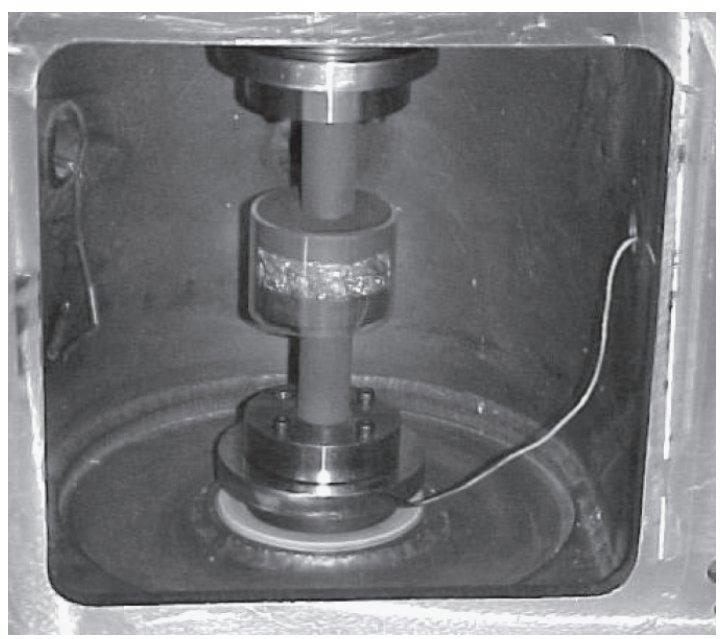

Fig.3 Photograph of the setup for sintering copper fiber under a low pressure.
化することで, 高性能なヒートシンクを軽量で提供すること が可能と考えられる.なお，試作したヒートシンクでは放熱 部分は銅線をコイル状に加工したものを利用しており,パル 又通電焼結により多孔質銅と接合させている.

3.2 短時間・高速焼結による耐食性材料の作製 $4-6)$

パルス通電焼結における標準的な黒鉛型を用いて, 30〜 40 MPaの加圧力による高速焼結を行った. 焼結する粉末には, メカニカルアロイング法で合成した $\mathrm{Fe}-48 \mathrm{at} \% \mathrm{Cr}$ 合金粉末を 用いた. $\mathrm{Fe}-\mathrm{Cr}$ 合金は耐食性に優れる ${ }^{4}$ が，高 $\mathrm{Cr}$ 含有合金に なると硬くて脆い $\sigma$ 相が生成することが知られている. Fe-48 at \% Cr 合金組成はちょうど $\sigma$ 相が生成する組成であり，溶解 法で合成すると $\sigma$ 相が生成する. Fe 粉末と Cr 粉末を出発原
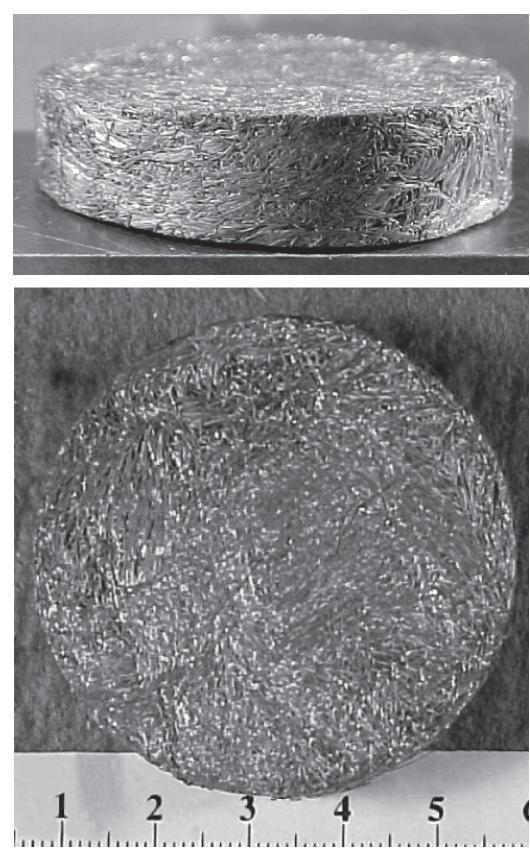

Fig.4 Photographs of top and side views of the porous copper prepared by pulsed current sintering under a low pressure.
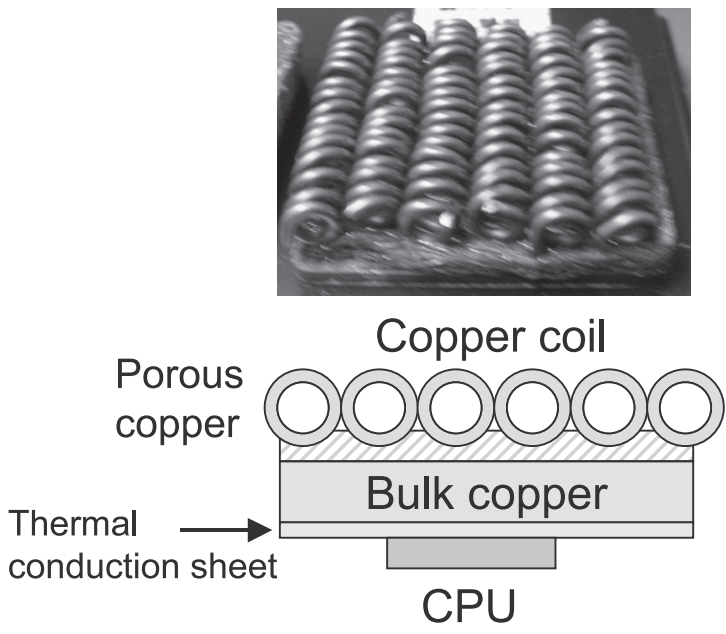

Fig.5 Photograph and schematic drawing of the experimental heat sink build up with bulk copper, porous copper and copper coils. 
料としてメカニカルアロイング5)を行うことで固溶体粉末を 作製することができる. 100 時間のメカニカルアロイング処 理で合成した粉末は $50 \sim 100 \mu \mathrm{m}$ の粒子であり, 微細な粉末 が凝集して造粒された状態であった.

この粉末を $33 \mathrm{MPa}$ の加圧下でパルス通電燒結 (SPS) で 1073-1173 Kにて固化成形した, 焼結は $10 \mathrm{~Pa}$ 程度の真空雾囲 気であり, 昇温速度は $50 \mathrm{~K} / \mathrm{min}$ の比較的高速とした. 得られ た焼結体を TEMにて組織観察すると， $1 \mu \mathrm{m}$ 程度の微細な結 晶粒6で構成されていることがわかった. 結晶粒のほとんど は BCC 構造であり, $\mathrm{Fe}-\mathrm{Cr}$ 固溶体であろうと考えられる, $\mathrm{X}$ 線回折を行って構成相を同定したが，焼結体には $\sigma$ 相の生成 は認められなかった.これは溶解法と違って, 耐火物として シリコンを用いないことが大きく寄与しているものと考えら れる.メカニカルアロイング法で Fe-Cr 合金を合成する際に シリコンを不純物として混入させると, パルス通電焼結体に はの相が生成していた. Fig.7に示す黒鉛型セットを用いて平 板状の引張試験片をパルス通電焼結により直接成形すること を試みた．C/Cコンポジットの円筒を外型として，その中に 黒鈶製の割り型をセットして通電焼結を行った. 粉末を充填 して加圧することで, 黒鉛型セットが崩れることはなかった. 得られた焼結体の外観をFig.8に示す.メカニカルアロイング 粉末を単純形状にパルス通電焼結した $\mathrm{Fe}-48 \mathrm{at} \% \mathrm{Cr}$ 合金から 機械加工で作製した試験片は，1 GPa を超える引張強度と $10 \%$ 以上の破断伸びを示すが, 直接成形した板状引張試験片

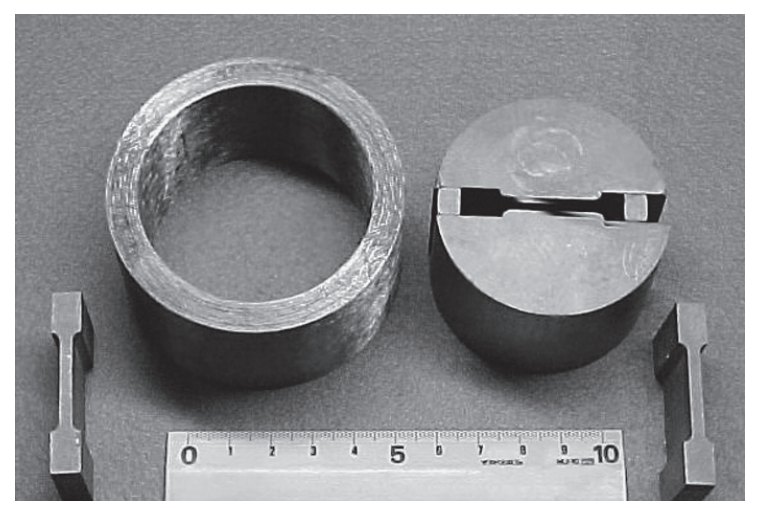

Fig.6 Photograph of the graphitic form: outer mold, inner mold and punches, for pulsed current sintering of $\mathrm{Fe}-\mathrm{Cr}$ alloy with complex shape.

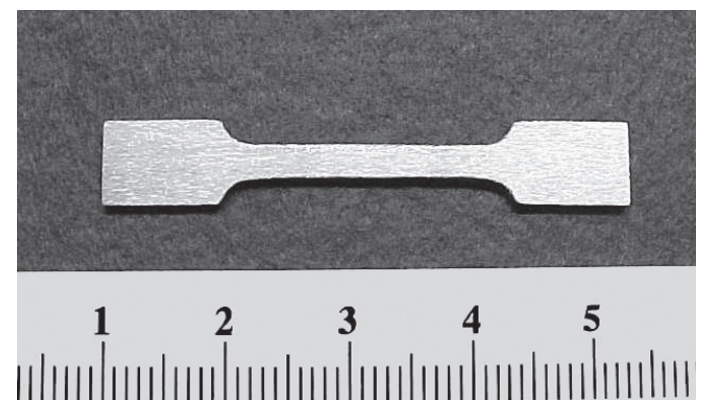

Fig.7 Photograph of Fe-48at\% Cr compact with complex shape prepared by pulsed current sintering.
では $700 \mathrm{MPa}$ 程度の引張強度しか示さなかった。これは, 焼 結後の冷却過程において黒鉆型の線膨張係数と焼結体の線膨 張係数の違いによりシャンク部と平行部の境目に大きな残留 応力が生じているためであると考えられる。実際, 試験片は シャンク部と平行部の境目で破断する場合が多かった. 残留 応力が作用しないような型の設計を行うことで, このような 複雑形状の成形体も直接成形できるものと考えられる.なお, 外型のC/Cコンポジットは成形時の圧力に耐えるだけでなく, 黒鉛型表面から輻射伝熱で失われる熱を㧕えることができた. これは，C/Cコンポジットが黒鉛型に比べて，多孔質である ためと考えられる.

3.3 高圧パルス通電焼結によるナノ結晶材料の作製 7-10)

メカニカルアロイング法などで作製したアモルファス粉末 をバルク化するためにパルス通電焼結が利用される場合があ る. バルクアモルファス材料は結晶粒界がなく, 耐食性に優 れ, 高強度が期待できる. 成形の際には, アモルファスの結 晶化温度以下の比較的低温で焼結を行うため, 大きな加圧力 で焼結する必要がある。例えば，メカニカルアロイング法で 合成したアモルファス粉末はダイヤモンドの成形方法である 超高圧成形によりバルク化することができる. パルス通電焼 結法では, 超高圧成形に比べて簡便である上, 粉末が導電性 である場合には粉末に直接流れた電流によって粉末接触部が 急速に加熱されて焼結することが考えられる. そのため, 粉 末表面が急速加熱と冷却を繰り返して, 緻密な成形体になる ものと考えられる.問題はパルス通電焼結時にいかにして大 きな成形圧力を付与するかである. そこで, 粉末をステンレ スパイプ内に充填し, ステンレスパイプごと $1.5 \mathrm{GPa}$ 程度の大 きな成形荷重を付与することにした. 型として超硬合金を用 い，873 K以下で固化成形することでバルクアモルファス材 料 7,8 を作製することができた. ただし，本プロセスで作製し たバルクアモルファス材料は成形時にクラックが導入されや すく，その機械的特性はあまり高くない，そこで, 結晶化温 度直上で固化成形することを試みた. 大きな加圧力下でアモ ルファスから結晶に変化した際にどのような焼結挙動が現れ るのか興味のあるところである.

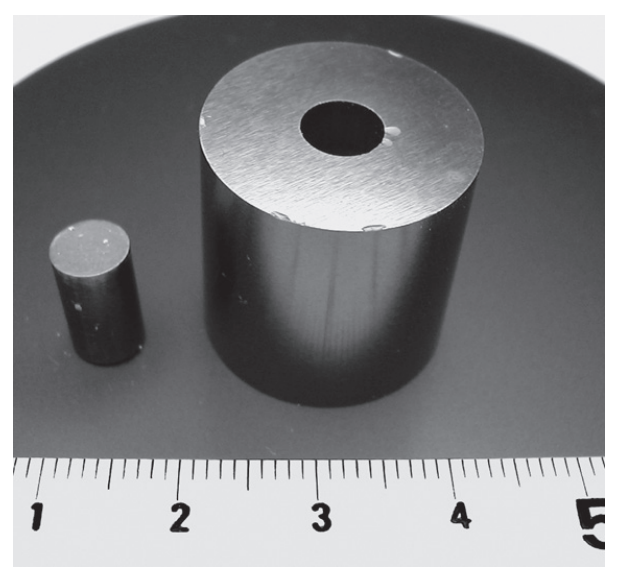

Fig. 8 Photograph of the cemented carbide die for pulsed current sintering of $\mathrm{Ti}-2$ at $\% \mathrm{Fe}-10$ at $\% \mathrm{Si}$ with a high pressure. 
Fig.8に示すような内径 $10 \mathrm{~mm}$, 外径 $30 \mathrm{~mm}$, 高さ $30 \mathrm{~mm}$ の 超硬合金製の型を用いて，500 MPa の加圧下でパルス通電焼 結を行った. 粉末はチタン粉末にシリコン粉末と鉄粉末を添 加してメカニカルアロイング法で合成したTi-2 at\% Fe-10at\% Siアモルファス粉末を用いた. シリコンはチタンのメカニカ ルアロイングにおける粉末生成を助長し，鉄はアモルファス 構造を作りやすくする役割を有する. 焼結温度は超硬合金製 型に $3 \mathrm{~mm}$ 程度挿入した $\mathrm{K}$ 型熱電対で測定しているため, 試料 温度とは少しずれが生じる.しかし，パルス通電焼結におい て結晶化温度を超えた時点から粉末は急激に収縮し始めた。 $\mathrm{Ti}-2 \mathrm{at} \% \mathrm{Fe}-10 \mathrm{at} \% \mathrm{Si}$ アモルファス粉末は結晶化温度直上で急 速に焼結し，ほぼ理論密度になることがわかった．得られた 焼結体の外観を Fig.9に示す．焼結体は割れもなく, $50 \mathrm{~nm}$ 程 度の微細組織で構成されていた。この焼結体の圧縮強度は Ti-6Al-4V合金の1.5倍以上であったが, 伸びはほとんど観察 されなかった. 本合金はチタンを主成分としているため耐食 性に優れており，Fig.10のように塩粉末を固化成形する際の 金型に利用することができた. 通電しながら大きな圧力で塩 を固化成形しても, 本合金は高い圧縮応力を有しているため,

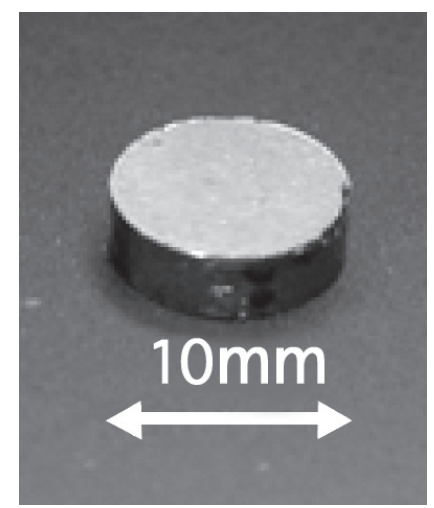

Fig.9 Photograph of nanocrystalline $\mathrm{Ti}-2$ at $\% \mathrm{Fe}-10$ at $\% \mathrm{Si}$ compact prepared by pulsed current sintering with a high pressure.

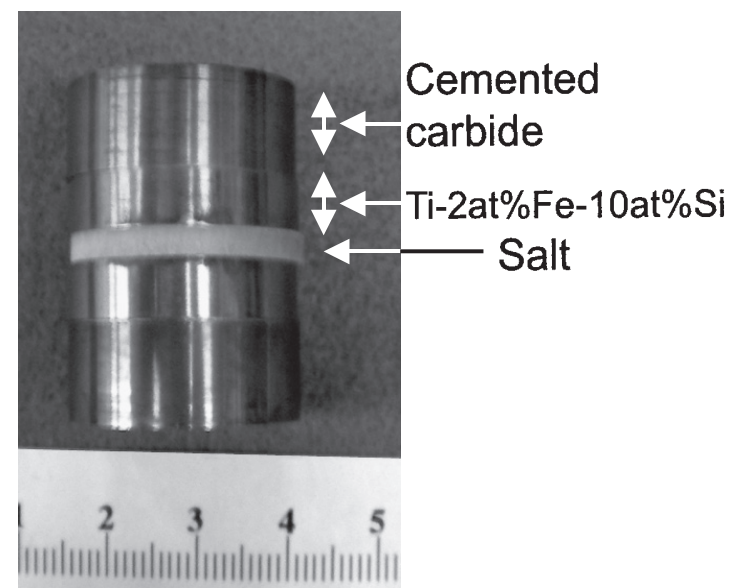

Fig.10 Photograph of the die-set build up with cemented carbide punch and $\mathrm{Ti}-2$ at $\% \mathrm{Fe}-10$ at\% $\mathrm{Si}$ punch for $\mathrm{NaCl}$ powder sintered by pulsed current sintering.
問題なく使用することができた. 塩粉末もパルス通電焼結で 固化成形することができ, スパッタなどで薄膜を作製する際 の基板に利用することができた.

3.4 高速パルス通電焼結装置の試作

パルス通電焼結装置は, チャンバー内を真空に引いてから 通電加熱を行うため, 高速昇温ができても全体の作業時間は 長くなる. また, 1 回の焼結で1個の焼結体しか得られないた め, その生産性は低い. そこで, パルス通電焼結の高速昇温 機構を利用して短時間で金属粉末を焼結する装置を試作した. プレス機構に機械的な機構(モーターの回転運動を利用)を利 用した高速プレス装置を用いた.このプレスの上ラムの移動 に合わせて通電を行い, 短時間で粉末を焼結しようとするも のである.ただ, 通電のON/OFFのタイミング制御が難しく, 機械的なスイッチを利用した制御では時間的なロスが大きく, 制御ができないことがわかった. そこで，パルスの形状 ( ス タート時間と通電時間など) をプレス機の運動に同調させ, 放電を抑制することに成功した。試作した装置の外観を Fig.11 に示す. 型に導電性の材料を用いると加熱温度は低く なるが，セラミックスなどの非導電性の型を用いることで, $745 \mathrm{~K}$ 程度まで加熱できることがわかった.アルミニウム粉 末をアルミナ製型 (パイプ内径 $5 \mathrm{~mm}$ ) に充填することで，八 ンドリングできる焼結体を作製することができた. 今後さら に最適な焼結条件を検討する予定である. なお, 本研究は経 済産業省の平成 17 年度中小企業支援事業としてエス・エス・ アロイと共同で実施した。

\section{4 ま とめ}

パルス通電焼結について, 焼結時の加圧力を制御すること によって機能性材料作製の可能性について検討した．特に， 加圧力は装置へ依存するものと考えられがちであるが, 稼動

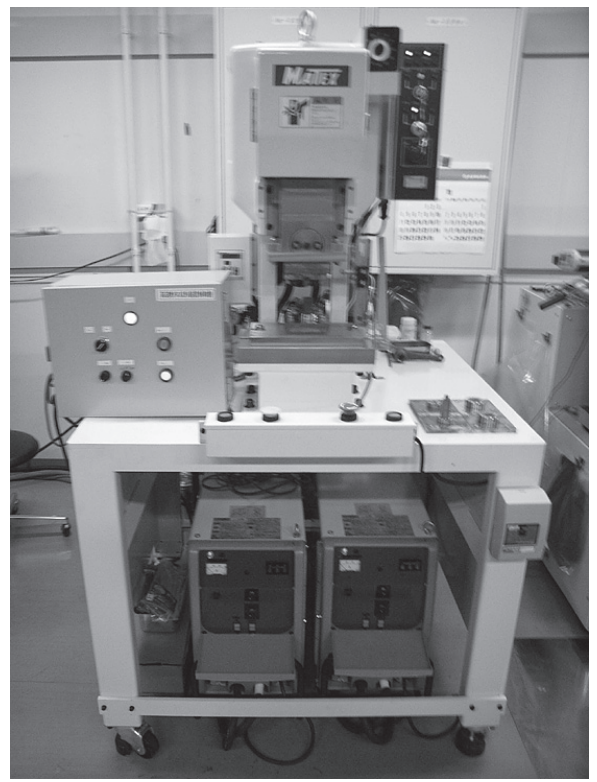

Fig.11 Photograph of the experimental apparatus for high-speed pulsed current sintering. 
ラムを少し改造することで $10 \mathrm{MPa}$ 以下の低圧から $1.5 \mathrm{GPa}$ での超高圧まで付与することができた. 加圧力を制御したパ ルス通電焼結を行い, パルス通電焼結の可能性として下記の ことを考えている.

（1）低圧パルス通電焼結では，多孔質成形体の作製に有効で あった．金属繊維や粉末を利用して任意の空隙率の成形 体を作製できるものと考えられる．粉末や繊維の接触部 分を高温にして溶着させるためにはパルス電流を付与す ることが有効であると考えられ，インバータなどの電源 が適していると考えられる.

(2) 黒鉆型を利用した高速昇温では微細結晶の成形体を作製 することができる. 特に, 平衡状態図で脆化相が生成する ような合金系においても，不純物の混入を抑制して高強 度で高い伸びを示す材料とすることができた．黒鉛型は 加工しやすいため, 複雑な形状をニアネット成形するこ とも可能である.

(3) 高圧を利用したパルス通電焼結では難焼結性の粉末をバ ルク化することができる.特に,アモルファス粉末など高 温で結晶化するような材料に対しても加圧力を大きくす ることでバルク化できる.Ti-2 at $\% \mathrm{Fe}-10 \mathrm{at} \% \mathrm{Si}$ アルファ ス粉末は結晶化温度直上で急激に緻密化が進行し, ナノ 結晶バルク材料を得ることができる.十ノ結晶 $\mathrm{Ti}-2 \mathrm{at} \% \mathrm{Fe}-$ 10at\%Si合金は耐食性に優れ, 圧縮強度も高いことから塩 のパルス通電焼結用金型へ利用することができた。

(4) パルス通電焼結の生産性の悪さを改善するため, 高速プ レスとパルス電源を同調する技術を開発し，短時間にパ ルス通電焼結できる装置を試作した.

\section{文献}

1) K.Kobayashi and K.Ozaki: "Development of Producing Hard-
Sintering Materials to Bulk Shape by Pulsed Current Sintering", J. Jpn. Soc. Powder Powder Metallurgy, 51 (2004) 19-26.

2) T.Nagae et al.: "Consolidation of a Hollow Compact by Pulse Discharge Pressure Sintering", J. Jpn. Soc. Powder Powder Metallurgy, 45(1998)169-171.

3) K.Ozaki, et al.: "Sintering Phenomena on Initial Stage in Pulsed Current Sinetering", J. Jpn. Soc. Powder Powder Metallurgy, 47(2000) 293-297.

4) N.Matsui et al.: "Effects of Cr Content on Mechanical Properties of Fe-Cr Alloy", J. Jpn. Soc. Powder Powder Metallurgy, 46(1999)1179-1184.

5) N.Matsui et al.: "Mechanical Property of $\mathrm{Fe}-48$ at\% Cr Alloy Prepared by MA-SPS Process", J. Jpn. Soc. Powder Powder Metallurgy, 47(2000)30-35.

6) K.Kobayashi et al.: "Net Shaping of Mechanically Alloyed Fe48 at\% Cr Powder by Pulsed Current Sintering Process", J. Jpn. Soc. Powder Powder Metallurgy, 47(2000) 1097-1101.

7) K.Kobayashi et al.: "Mechanically Alloying and High Pressure Pulsed Current Sintering of Si added Ti Powder", J. Japan Inst. Metals, 65(2001)179-182

8) K.Kobayashi et al.: "Pulsed Current Sintering of Amorphous Titanium Alloy Powder Synthesized by Mechnical Alloying Process", Materials Transaction, 44(2003) 144-147.

9) K.Kobayashi et al.: "Preparation and Characterization of Nanocrystalline Ti-2 at\% $\mathrm{Fe}-10$ at\% Si Alloy by Mechanical Alloying and Pulsed Current Sintering Process", J. Japan Inst. Metals, 67(2003) 177-180.

10) K.Kobayashi et al.: "Characteristic of $\mathrm{Ti}-2$ at $\% \mathrm{Fe}-10$ at $\% \mathrm{Si}$ Powder Synthesized by Mechanical Alloying", J. Jpn. Soc. Powder Powder Metallurgy, 50(2003)205-209. 